Article

\title{
Bioconversion of Sweet Sorghum Residues by Trichoderma citrinoviride C1 Enzymes Cocktail for Effective Bioethanol Production
}

\author{
Anna Kancelista ${ }^{1, *(\mathbb{D}}$, Joanna Chmielewska ${ }^{2} \mathbb{D}$, Paweł Korzeniowski ${ }^{1}$ and Wojciech Laba $^{1}$ (D) \\ 1 Department of Biotechnology and Food Microbiology, Wroclaw University of Environmental and Life \\ Sciences, 37 Chełmońskiego Street, 51-630 Wrocław, Poland; pawel.korzeniowski1@upwr.edu.pl (P.K.); \\ wojciech.laba@upwr.edu.pl (W.Ł.) \\ 2 Department of Fermentation and Cereals Technology, Wroclaw University of Environmental and Life \\ Sciences, 37 Chełmońskiego Street, 51-630 Wrocław, Poland; joanna.chmielewska@upwr.edu.pl \\ * Correspondence: anna.kancelista@upwr.edu.pl; Tel.: +48-71-320-7735
}

Received: 20 October 2020; Accepted: 6 November 2020; Published: 8 November 2020

\begin{abstract}
Improved cost-effective bioethanol production using inexpensive enzymes preparation was investigated. Three types of waste lignocellulosic materials were converted-for the production of enzyme preparation, a mixture of sugar beet pulp and wheat bran, while the source of sugars in hydrolysates was sweet sorghum biomass. A novel enzyme cocktail of Trichoderma citrinoviride C1 is presented. The one-step ultrafiltration process of crude enzyme extract resulted in a threefold increase of cellulolytic and xylanolytic activities. The effectiveness of enzyme preparation, compared to Cellic ${ }^{\circledR}$ CTec2, was tested in an optimized enzymatic hydrolysis process. Depending on the test conditions, hydrolysates with different glucose concentrations were obtained-from $6.3 \mathrm{~g} \mathrm{~L}^{-1}$ to $14.6 \mathrm{~g} \mathrm{~L}^{-1}$ (representing from $90 \%$ to $79 \%$ of the CTec2 enzyme yield, respectively). Furthermore, ethanol production by Saccharomyces cerevisiae SIHA Active Yeast 6 strain DF 639 in optimal conditions reached about $120 \mathrm{~mL} \mathrm{~kg} \mathrm{d.m.}{ }^{-1}$ (75\% compared with the CTec2 process). The achieved yields suggested that the produced enzyme cocktail C1 could be potentially used to reduce the cost of bioethanol production from sweet sorghum biomass.
\end{abstract}

Keywords: lignocellulose; waste biomass; saccharification; microbial fermentation; 2G ethanol; Box-Behnken design

\section{Introduction}

Industrial development is associated with an increasing energy demand. This concern affects all branches of industry, with transportation ranked at the top. Growing production of cars comes with further higher fuel consumption. Unavoidable depletion of fossil fuels, which are commonly used as main energy sources, poses both economic and ecological hazards. A great alternative to fossil fuels is offered by biofuels [1]. Biofuels, like bioethanol, are produced from crops which are renewable sources; however, growing crops especially for fuel production may cause further practical problems due to competition between biofuel and food crops in the cultivation area. A solution to this problem is the production of second-generation bioethanol (2G) [1] from cellulose-rich plant biomass, predominantly agriculture wastes, which is connected with significantly reduced costs. One of the substrates available for $2 \mathrm{G}$ bioethanol production is sweet sorghum bagasse (SSB), a lignocellulosic material left after the sucrose-rich juice has been extracted from the plants [2]. Sweet sorghum itself is a plant able to grow in fifth class soil due to its deep root system and resistance to drought as well as many plant diseases and pests. These features make sorghum the fifth most cultivated crop in the world, resulting in SSB being an inexpensive fermentation substrate source [3-5]. Ethanol produced from sweet sorghum is 
safer for the environment due to low sulfur content, low biological and chemical oxygen demand, and a high octane rating. While annual ethanol output from sweet sorghum depends on several factors, including genetic background, season, soil quality, and other environmental factors, the annual ethanol production from sweet sorghum crop is estimated at $8000 \mathrm{~L} / \mathrm{ha}$ [6].

Obtaining a suitable substrate for the production of $2 \mathrm{G}$ bioethanol is merely the initial step; however, a further major concern is saccharification of cellulose, since fermenting yeasts are unable to use sugar polymers. Substrates used in this process (i.e., SSB) need to be chemically/physically pretreated and then enzymatically hydrolyzed prior to the fermentation step. An initial pretreatment is essential to make raw materials accessible to the hydrolyzing enzymes [7]. This step involves mostly acidic or alkaline treatment of the substrate, although such methods as microwave radiation, sonification, spray drying, gamma radiation, and pyrolysis are employed as well [8]. The second step of treatment, widely covered in this article, includes enzymatic hydrolysis, typically performed with the use of commercial enzymatic preparations. Cellulase preparations available on the market derive from different microorganisms, such as: Aspergillus sp., Trichoderma sp. (T. longibrachiatum, T. reesei, T. viride, and T. harzianum), Humicola sp. (H. insolens and H. griseathermoidea), or Bacillus sp. [9]. These preparations are costly, for example, the price of CTec2 according to the data of one of the largest distributors of enzyme preparations is $€ 120$ per $50 \mathrm{~mL}$ (Sigma-Aldrich, St. Louis, MO, USA). This article introduces a new enzymatic preparation from Trichoderma citrinoviride $\mathrm{C} 1$, produced in a less complex and low-cost process involving two simple steps, as a promising alternative to commercial counterparts.

The efficiency of a cellulase preparation, whether commercial or not, depends on such process parameters as $\mathrm{pH}$, temperature, and substrate concentration. To achieve its peak efficiency, the saccharification process conditions require optimization. The objective of this study was to produce a new cellulase preparation but also to optimize hydrolysis parameters of sweet sorghum waste biomass ( $\mathrm{pH}$, temperature, and substrate concentration), as well as to assess their usefulness in the process of substrate pretreatment for ethanol fermentation. The efficiency results obtained in this research were compared to those acquired with a commercially viable enzyme for cellulosic ethanol production (Cellic ${ }^{\circledR} \mathrm{CTec} 2$ ) to establish applicability of the enzymatic preparation produced in the study.

\section{Results}

Biosynthesis of cellulolytic and xylanolytic enzymes was performed in 10-day solid state fermentation of $T$. citrinoviride $\mathrm{C} 1$ with confirmed capability for extracellular synthesis of these hydrolases, in culture medium based on a mixture of wheat bran and sweet beet pulp. The enzymatic activity determined in the post-culture liquid reached $2.37 \mathrm{U} \mathrm{mL}^{-1}$ and $6.52 \mathrm{U} \mathrm{mL}^{-1}$ for cellulases and xylanases, respectively (Table 1).

Table 1. Enzyme yields and purification factors after ultrafiltration process.

\begin{tabular}{cccc}
\hline & Units & CMCases & Xylanases \\
\hline Enzymatic activity of post-culture liquid & {$\left[\mathrm{U} \mathrm{mL}^{-1}\right]$} & 2.37 & 6.52 \\
Enzymatic activity of concentrated preparation & {$\left[\mathrm{U} \mathrm{mL}^{-1}\right]$} & 8.99 & 21.26 \\
Total activity of post-culture liquid & {$[\mathrm{U}]$} & 1898 & 5216 \\
Total activity of concentrated preparation & {$[\mathrm{U}]$} & 1798 & 4252 \\
Specific activity of post-culture liquid & {$\left[\mathrm{U} \mathrm{mg}^{-1}\right]$} & 0.51 & 1.41 \\
Specific activity of concentrated preparation & {$\left[\mathrm{U} \mathrm{mg}^{-1}\right]$} & 0.80 & 1.88 \\
Recovery & {$[\%]$} & 94.75 & 81.52 \\
Purification factor & & 1.56 & 1.33 \\
\hline
\end{tabular}

The ultrafiltration step resulted in a more than three-fold increase in enzymatic activity per volume unit. The concentrated preparation exhibited the activity of cellulases $\left(8.99 \mathrm{U} \mathrm{mL}^{-1}\right)$ and xylanases $\left(21.26 \mathrm{U} \mathrm{mL}^{-1}\right)$, whereas the enzymatic protein recovery yield was not lower than $80 \%$ and the degree of purification was not higher than 1.6 (Table 1). 
The low degree of purification was due to the single-stage purification process; however, the determined enzymatic activity of the preparation was at a satisfactory level, which allowed to use it for the enzymatic hydrolysis of sorghum waste biomass. In the commercial enzyme cellulolytic activity of $185.42 \mathrm{U} \mathrm{mL}^{-1}$ was determined; however, both preparations were applied for the process of hydrolysis at similar doses of $2.15 \mathrm{U}$ of endocellulases (CMCases) per $10 \mathrm{~g}$ of substrate.

The increase in sugar concentration $(\Delta)$ after the enzymatic hydrolysis process in relation to their amount after the applied prehydrolysis process is presented in Figure 1. Enzymatic saccharification was carried out under various conditions (substrate concentration, temperature, and $\mathrm{pH}$ ) with the synthesized enzyme C1 (a) and the commercial enzyme preparation CTec2 (b). Concentrations of a mixture of galactose + xylose + mannose and of arabinose were higher in the hydrolysates made with $\mathrm{C} 1$ preparation, compared to the commercial CTec2 preparation, except for the variant with the medium concentration of the substrate $(21 \%)$ hydrolyzed at $58^{\circ} \mathrm{C}$ and $\mathrm{pH} 5.5$. In turn, in hydrolysates produced with the CTec2 preparation higher concentrations of glucose were obtained as a result of dominant cellulolytic activity. This had a direct impact on the efficiency of the hydrolysis process calculated in relation to glucose, and in the experiment involving CTec2 preparation, its value ranged from $9.25 \%$ (run 10 ) to $16.93 \%$ (run 1) (data not shown).

a)

a) $\quad \Delta$ glu $\square \Delta$ gal, xyl, man $\square \Delta$ arab

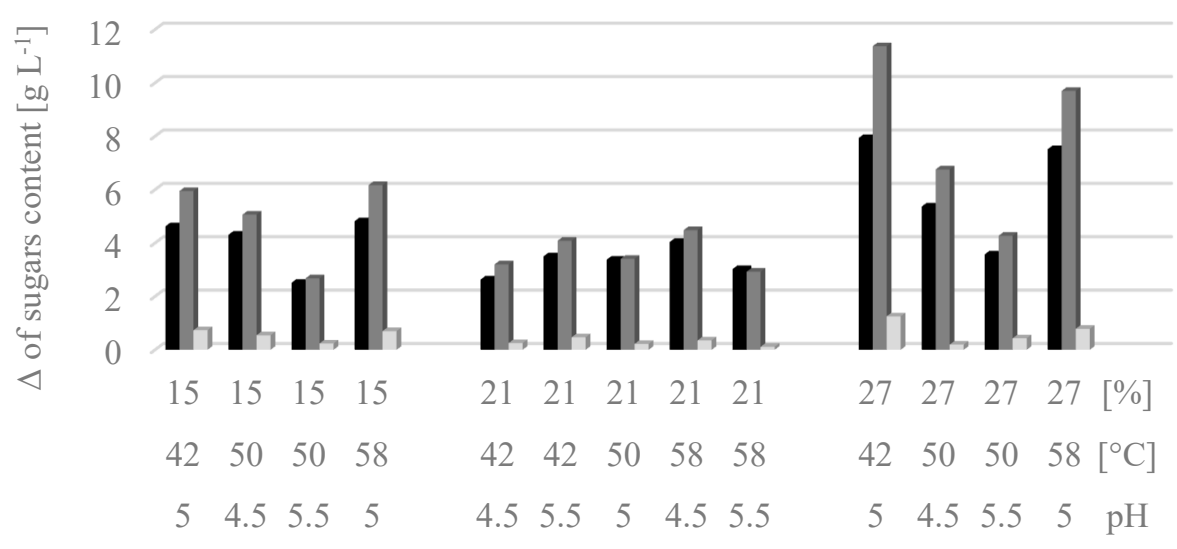

b) $\quad \Delta$ glu $\square \Delta$ gal, xyl, man $\square \Delta$ arab

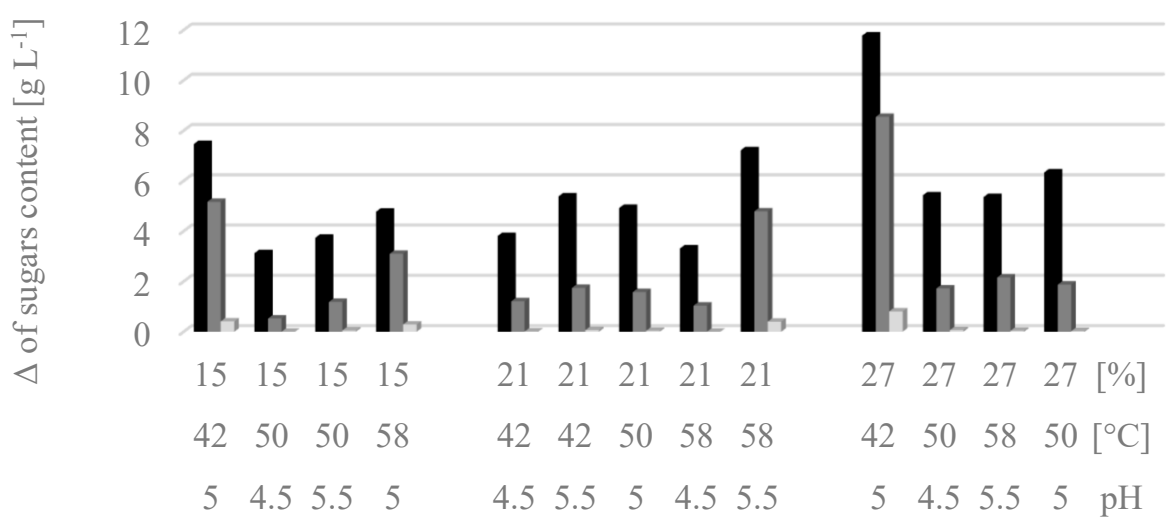

Figure 1. Comparison of changes in sugar content after the hydrolysis step conducted under various conditions (substrate concentration, temperature, $\mathrm{pH}$ ) with (a) $\mathrm{C} 1$ and (b) CTec2 enzymes. 
Considering the effectiveness of enzymatic hydrolysis performed with the preparation obtained under laboratory conditions, the variants with the maximum analyzed concentration of the substrate at $\mathrm{pH} 5.0$ were the most advantageous. The sugars were released to hydrolysates as a result of prehydrolysis and enzymatic hydrolysis processes. The efficiency of the first step ranged from 39 to $46 \%$. In turn, the efficiency of the enzymatic hydrolysis processes depended mainly on the process conditions, but the preparation used had no influence here because the efficiency in both processes ranged from $17 \%$ to $46 \%$ (Figure 2).

a)

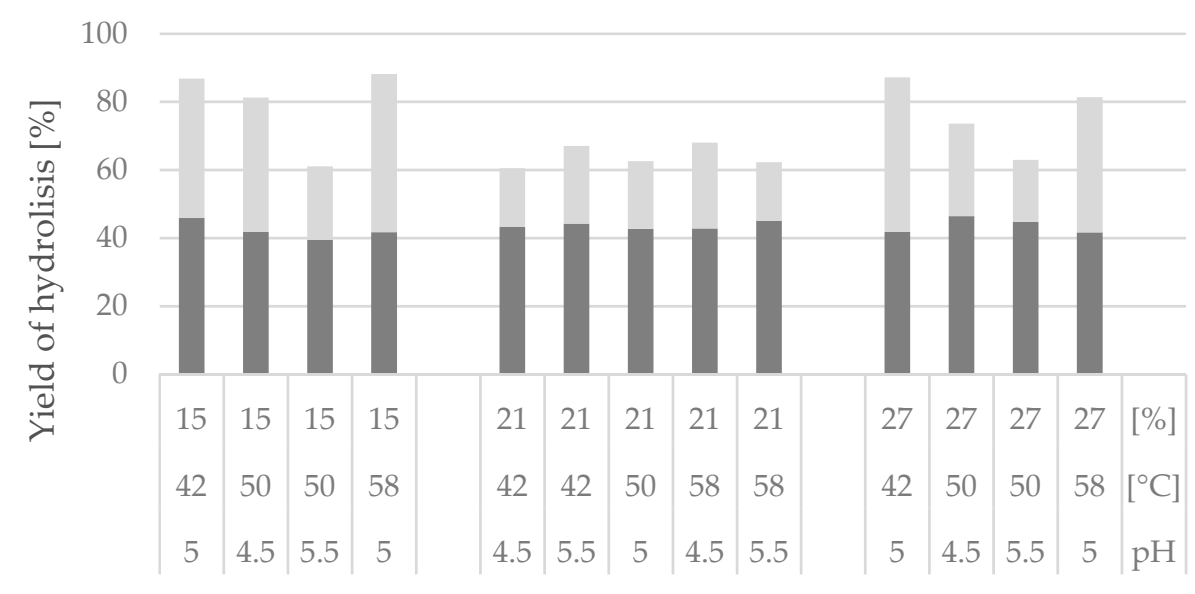

b)

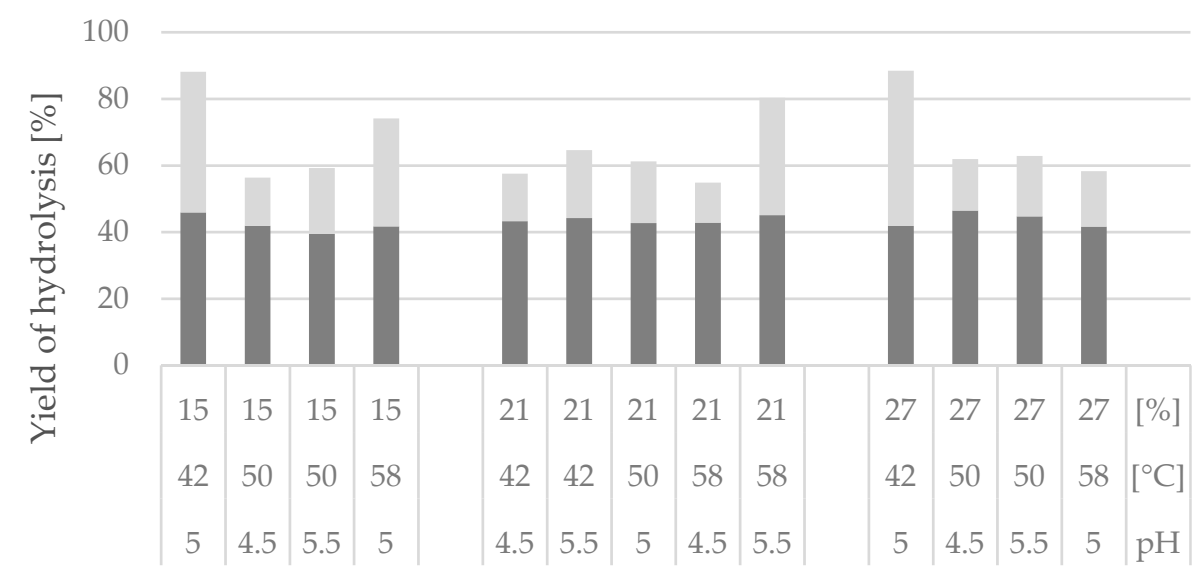

Figure 2. Efficiency of the prehydrolysis and enzymatic hydrolysis process with (a) $\mathrm{C} 1$ and (b) CTec2 enzymes.

Employing separate enzymatic hydrolysis and fermentation in ethanol production from lignocellulosic materials enables better adjustment of process conditions to these, conditions optimal for the effective action of both enzymatic preparations and Saccharomyces cerevisiae yeast, compared to the processes involving simultaneous hydrolysis and fermentation. Figure 3 presents response surface models depicting the effect of substrate concentration and temperature on the yield of ethanol fermentation performed with $\mathrm{C} 1$ and CTec2 enzymes at the stage of substrate pretreatment. 
a)

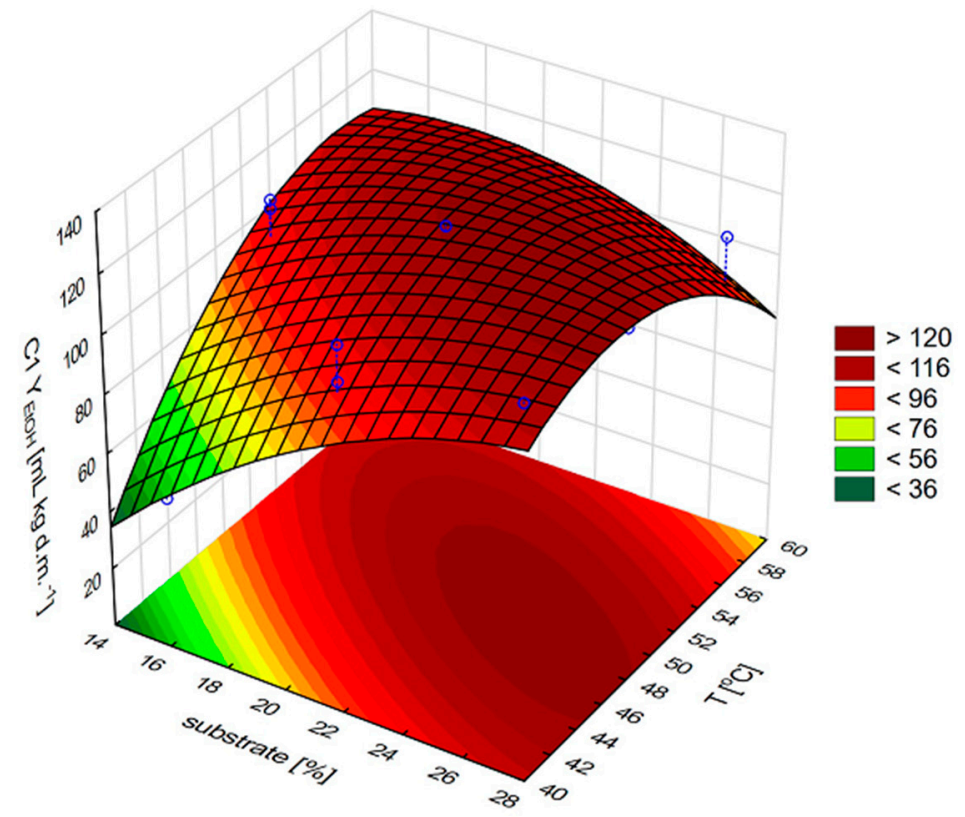

b)

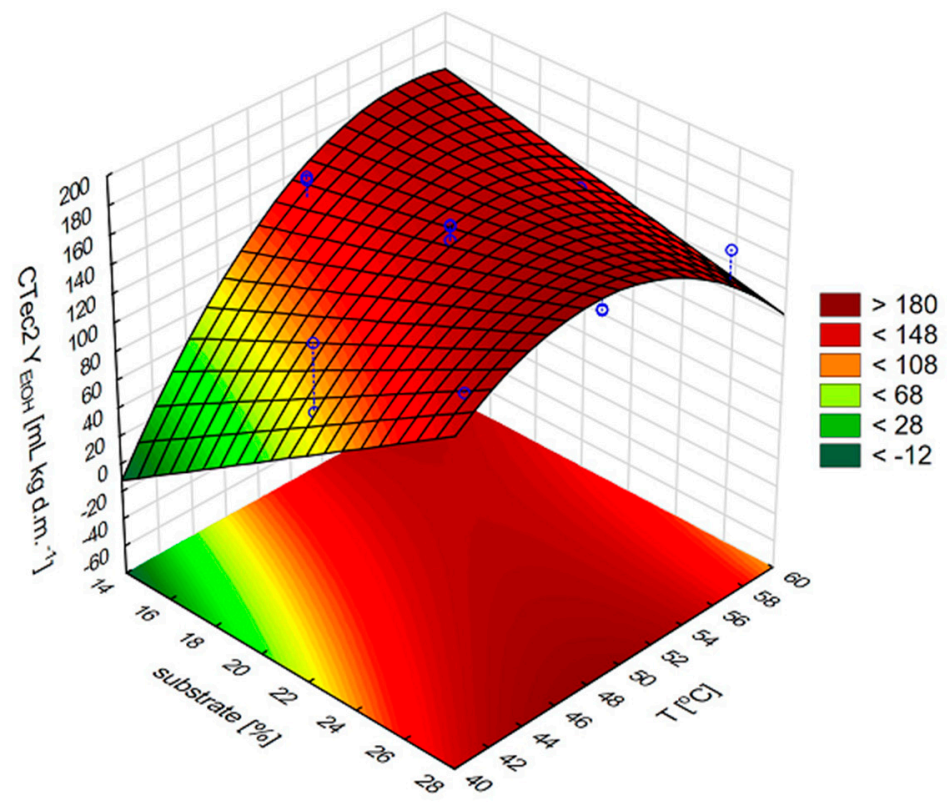

Figure 3. Comparison of response surface plots of the interaction effects between substrate concentration and temperature on ethanol yield in SHF processes with C1 (a) and CTec2 (b) enzymes.

Statistically significant effects of substrate concentration and process temperature were demonstrated, whereas there was no significant impact of $\mathrm{pH}$ value change, expressed both in the linear and quadratic effect, on the yield of ethanol fermentation process.

Ethanol yield after completed fermentation of the hydrolysates obtained with $\mathrm{C} 1$ and $\mathrm{CTec} 2$ preparations, depending on the experience option, ranged from 40.2 to 122.5 and from 3.5 to $165.3 \mathrm{~mL} \mathrm{~kg} \mathrm{d.m.}{ }^{-1}$, respectively (Table 2). Taking into account that the yeasts used in the ethanol fermentation process from the total sugar content in hydrolysates were only able to use hexoses, the theoretical efficiency of the process was relatively high (Table 2), up to approximately $57 \%$ when using $\mathrm{C} 1$ and up to $76 \%$ for $\mathrm{CTec} 2$ preparation. 
Table 2. Experimental design with actual and predicted responses in the Box-Behnken model.

\begin{tabular}{|c|c|c|c|c|c|c|c|c|c|}
\hline \multirow{3}{*}{ Run } & \multicolumn{3}{|c|}{ Independent Variables } & \multicolumn{2}{|c|}{$\begin{array}{c}\text { Ethanol Yield } \\
\text { [\% of Theoretical] }\end{array}$} & \multicolumn{4}{|c|}{ Ethanol Yield [mL kg d.m. ${ }^{-1}$ ] } \\
\hline & \multirow{2}{*}{$\mathrm{X}_{1}$ Substrate [\%] } & \multirow{2}{*}{$\begin{array}{l}\mathrm{X}_{2} \mathrm{~T} \\
{\left[{ }^{\circ} \mathrm{C}\right]}\end{array}$} & \multirow{2}{*}{$\begin{array}{l}\mathrm{X}_{3} \\
\mathrm{pH}\end{array}$} & \multirow{2}{*}{$\mathrm{C} 1$} & \multirow{2}{*}{ CTec2 } & \multicolumn{2}{|c|}{ C1 } & \multicolumn{2}{|c|}{ CTec2 } \\
\hline & & & & & & Actual Value & Predicted Value & Actual Value & Predicted Value \\
\hline 1 & 15 & 42 & 5.0 & 12.92 & 1.12 & 40.207 & 58.802 & 3.524 & 35.805 \\
\hline 2 & 27 & 42 & 5.0 & 36.59 & 48.88 & 114.330 & 114.873 & 154.927 & 154.706 \\
\hline 3 & 15 & 58 & 5.0 & 33.92 & 56.34 & 107.143 & 110.452 & 149.679 & 161.515 \\
\hline 6 & 27 & 50 & 4.5 & 44.65 & 71.62 & 117.809 & 120.336 & 158.930 & 179.019 \\
\hline 7 & 15 & 50 & 5.5 & 50.01 & 70.49 & 109.384 & 100.001 & 149.623 & 135.455 \\
\hline 8 & 27 & 50 & 5.5 & 48.15 & 70.96 & 108.663 & 120.336 & 159.866 & 179.019 \\
\hline 9 & 21 & 42 & 4.5 & 52.02 & 65.36 & 112.795 & 97.196 & 134.699 & 95.256 \\
\hline 10 & 21 & 58 & 4.5 & 45.69 & 73.16 & 111.358 & 113.110 & 143.835 & 145.628 \\
\hline 11 & 21 & 42 & 5.5 & 41.90 & 37.94 & 100.735 & 97.196 & 87.874 & 95.256 \\
\hline
\end{tabular}

In terms of sugars consumed, fermentation of hydrolysates obtained with the $\mathrm{C} 1$ preparation allowed to obtain 66 to $280 \mathrm{~mL}$ of ethanol, while fermentation of CTec2 hydrolysates, from 6 to $377 \mathrm{~mL}$ of ethanol, calculated per kg of sugars (Figure S1). Regardless of the enzymatic preparation, the highest bioethanol yields were achieved at substrate concentration of $21 \%$ and hydrolysis conducted at a temperature of $50^{\circ} \mathrm{C}$ and $\mathrm{pH} 5.0$.

The course of prediction profiles plotted for the proposed experimental model (Figure S2) enabled the establishment of the optimal process conditions. The determined conditions for the application of the $\mathrm{C} 1$ preparation were as follows: Substrate concentration $22.6 \%$, temperature $50.5^{\circ} \mathrm{C}$, and $\mathrm{pH}$ 5.1; they allowed achieving ethanol yield at $122.5 \mathrm{~mL} \mathrm{~kg} \mathrm{d.m.}{ }^{-1}$. In the case of the commercial CTec2 preparation, the respective conditions were: $27 \%, 52.7^{\circ} \mathrm{C}$, and $\mathrm{pH} 5.2$, and predicted ethanol yield was at $170.8 \mathrm{~mL} \mathrm{~kg} \mathrm{d.m.}{ }^{-1}$.

Both obtained regression models were analyzed with ANOVA to verify their correctness. Significance of the models was confirmed by achieved F-values and adherence of models to the measured data was described by coefficients of determination $\left(R^{2}\right)$. For the process with $C 1$ enzyme preparation F-value was 5.01 and $\mathrm{R}^{2}$ 0.7358. For the hydrolysis with CTec2 F-value reached 7.83 and $\mathrm{R}^{2}$ 0.8132 (Table S1). Furthermore, the "lack of fit" tests were insignificant for both models, which further proved their correctness.

The empirical relationship between predicted ethanol yield and the variables substrate concentration and temperature was expressed as a polynomial equation:

$$
\mathrm{C} 1 \mathrm{y}=-1083.09+32.39 \mathrm{X}_{1}+32.83 \mathrm{X}_{2}-0.29 \mathrm{X}_{1}^{2}-0.24 \mathrm{X}_{2}{ }^{2}-0.37 \mathrm{X}_{1} \mathrm{X}_{2}
$$

and

$$
\mathrm{CTec} 2 \mathrm{y}=132.71+43.56 \mathrm{X}_{1}-50.37 \mathrm{X}_{2}+36.79 \mathrm{X}_{2}{ }^{2}-75.34 \mathrm{X}_{1} \mathrm{X}_{2}
$$

\section{Discussion}

Reduction in the amount of generated wastes is contemporarily an urgent goal to achieve. Some waste materials may be successfully used as substrates in biotechnological processes. This is the case with, e.g., lignocellulosic waste biomass produced in large volumes as a result of agricultural activity or as a waste product in food processing, thus posing a great problem to the natural environment protection due to a lack of its management strategies. Part of the waste biomass is spent as feedstuff; however, its vast amounts significantly surpass the needs in this respect. On the other hand, this waste material offers an excellent source of carbon and energy to microorganisms, which has been exploited for years. One of the waste biomass management sectors may be production of hydrolytic enzymes and second-generation bioethanol. Due to their composition, such lignocellulosic waste materials 
as vegetable and fruit peels, fruit pomace, sugar cane, pomace from oil production, wheat straw, wheat bran, and sugar beet pulp are often utilized for cultivation of bacteria and filamentous fungi aimed at the synthesis of cellulases, xylanases, lipases, and pectinases [10-14]. A tendency has been recently observed for the use of these waste materials in solid media cultures, which appeared to be superior in terms of cost-effectiveness, environment-friendly character, and yield compared to submerged cultures [15-17].

Lignocellulosic waste materials, as an inexpensive and readily available source of carbon and energy, are commonly used as substrates in the production of enzymes, in particular cellulolytic and xylanolytic. In the present study, a mixture of sugar beet pulp and wheat bran was used for the biosynthesis of cellulolytic and xylanolytic enzymes in a solid state culture, which allowed achieving enzymatic activity at $21.5 \mathrm{U} \mathrm{g}^{-1}$ and $59.27 \mathrm{U} \mathrm{g}^{-1}$ medium, respectively. Using the solid medium composed of sugar beet pulp only and the same strain of filamentous fungi, Piegza et al. [18] obtained cellulolytic activity at $6.0 \mathrm{U} \mathrm{g}^{-1}$, which may indicate that a mixture of substrates is a better inducer of cellulolytic enzymes compared to a single substrate. Similar observations were made by Mala et al. [19], who proved that the use of two substrates for lipases production enhanced their biosynthesis by $36 \%$.

From among other carbon sources (wheat bran, rice straw, sugar cane pulp, wheat straw) used by Idris et al. [20], wheat bran turned out to be the most advantageous inducer of cellulase production by Trichoderma reesei RUT C-30, which allowed for an exceptionally high activity of 298.4 $\mathrm{U} \mathrm{g}^{-1}$. The selection of the waste material for the process of biosynthesis is dependent on its availability in a specific country; hence, in this study a mixture of beet pulp and wheat bran was used, which represent raw materials commonly found in Poland as food industry by-products. Currently, numerous publications are available on the application of microorganisms in the biosynthesis of cellulases and xylanases. To summarize their contribution, we can conclude that most common producers are saprophytes isolated primarily from soil, organic residues found in forests and composts, which are classified mainly among bacteria, actinomycetes and filamentous fungi [21,22]. In addition, the white-rot basidiomycetes, or Shiitake medicinal mushroom Lentinus edodes (higher Basidiomycetes) are also known as cellulase producers [23,24].

In scientific works, the most frequently discussed are issues related to the pretreatment of lignocellulose, the use of various carbon sources (hexoses, pentoses) and various techniques (separate hydrolysis and fermentation, simultaneous saccharification and fermentation, simultaneous saccharification and co-fermentation, and consolidated bioprocessing) promoting high ethanol yield and cost-efficiency of the entire bioprocess [25].

In addition, the enzymatic preparation used in the production of second-generation (2G) ethanol is a significant determinant of the yield and profitability of the entire process. Many commercial preparations are available on the market; however, their excessive cost prevents their industrial-scale application. This urges the need for developing a technology that would exploit an inexpensive preparation, often produced with filamentous fungi Trichoderma sp. Some authors have suggested that when pure glucose was used to produce the enzymatic preparation, its price would account for even $50 \%$ of preparation production cost [26]. The $\mathrm{C} 1$ preparation was produced using lignocellulosic waste materials, which substantially increases its attractiveness. Despite a single-stage ultrafiltration process, the enzymatic activity of the preparation did not differ significantly from results reported by other authors $[27,28]$. Using a membrane with the cut-off point of $10 \mathrm{kDa}$ in the concentration process enabled retention of (hemi)cellulolytic proteins in the concentrated syrup. The use of such a membrane in our study allowed for over $80 \%$ recovery of determined enzymes. A marginally lower recovery percentage was obtained by Qi et al. [29] who managed to retain $78 \%$ of proteins in the preparation after the ultrafiltration process. Mores et al. [30], who also used a $10 \mathrm{kDa}$ cut-off membrane, confirmed that it allowed for an effective recovery of cellulolytic enzymes. These examples demonstrate the right choice of this type of membrane for the production of a concentrated preparation.

Substrate pretreatment, involving breakdown of the compact structure of lignocellulose, is known to be a crucial stage in $2 \mathrm{G}$ bioethanol production, determining the effectiveness of the entire process. 
In the above study, likewise in research of Głab et al. [31], the substrate pretreatment involved the acidic pre-hydrolysis. In turn, Cao et al. [32] compared various methods for sorghum biomass pre-hydrolysis and achieved the best result upon the coupled use of a diluted sodium hydroxide solution and hot hydrogen peroxide. However, the application of multiple chemical reagents has an adverse effect on the natural environment and, therefore, the least interfering methods should be looked after. It is also worthy of notice that the outcomes of hydrolysis and fermentation are affected by inhibitors produced during substrate pretreatment. Treating the lignocellulosic substrate with acid causes primarily hemicellulose degradation to monosaccharides, but additionally induces synthesis of such compounds as phenols, furfural or 5-hydroxymethylfurfural, which may inhibit activity of enzymes and microorganisms in the fermentation process. Teixeira et al. [33] analyzed the composition of inhibitors, i.e., furfural, 5-hydroxymethylfurfural (HMF) and acetic acid, in acidic, basic, and enzymatic hydrolysates of sugar cane pulp. The highest concentrations of HMF and furfural were determined in acidic hydrolysates obtained with $7 \%$ sulfuric acid (VI). These authors concluded that the accumulation of both these compounds increased proportionally with the increasing acid concentration. In turn, the enzymatic hydrolysates analyzed in their study had a high concentration of acetic acid. In recent years, various authors have proposed natural pretreatment methods which—when optimized—could offer an alternative to the chemical methods [34,35].

Undoubtedly, a key element for reaching a high bioethanol yield from plant waste is the stage of enzymatic hydrolysis. Its conditions should be adjusted individually to the specific substrate. Performing enzymatic hydrolysis with a specified dose of endocellulases allowed for comparing the effectiveness of $\mathrm{C} 1$ preparation with that of the commercial CTec2 preparation. This comparative analysis demonstrated a diverse effect of both preparations on process yield due to the presence of accompanying enzymes.

Ethanol yields obtained during fermentation of the hydrolysates produced with the laboratory and commercial enzymatic preparation were consistent with those reported in literature, even though conditions of the fermentation process had not been optimized. Employing acidic pre-hydrolysis of sorghum waste biomass, Gibbons et al. [36] achieved ethanol yield at $141 \mathrm{~g} \mathrm{~kg}^{-1}$ dry sorghum (178.5 mL kg ${ }^{-1}$ dry sorghum). Kim and Day [37] produced $97 \mathrm{~g}(122.8 \mathrm{~mL})$ of ethanol from one $\mathrm{kg}$ of sweet sorghum dry matter. In turn, Salvi et al. [38] achieved from 210 to $250 \mathrm{~g}$ (from 265.8 to $316.4 \mathrm{~mL}$ ) of ethanol $\mathrm{kg}^{-1}$ dry sorghum biomass using a diluted ammonia pretreatment ( $28 \% v / v$ ammonium hydroxide at $160^{\circ} \mathrm{C}$ for $1 \mathrm{~h}$ ) and enzymatic hydrolysis (Spezyme $\mathrm{CP}$ and Novozyme 188). Furthermore, impregnation of sweet sorghum bagasse $2.5 \% \mathrm{SO}_{2}$ at a temperature of $200{ }^{\circ} \mathrm{C}$ for $7.5 \mathrm{~min}$ coupled with enzymatic hydrolysis (Spezyme CP and Novozyme 188) resulted in ethanol yield of $153 \mathrm{~g}(193.7 \mathrm{~mL})$ from $\mathrm{kg}$ of substrate dry matter [39].

Future investigations should attempt to simplify the technological process and to minimize the inhibitory effect of hydrolysis products, accumulated in the medium through the simultaneous saccharification and fermentation (SSF) or semi-simultaneous saccharification and fermentation (SSSF) [40] with the use of the enzymatic preparation obtained under laboratory conditions in our study. In turn, conditions of the fermentation process could be improved by supplementing fermentation media with components that demonstrate a positive impact on yeast condition [41,42]. In addition, due to the synthesis of pentoses and significant amounts of xylose upon hemicelluloses hydrolysis, it would seem advisable to make use of unconventional microorganisms capable of ethanol fermentation of pentoses.

\section{Materials and Methods}

\subsection{Microorganisms}

The enzymatic preparation used in the study was produced using Trichoderma citrinoviride C1 fungus strain with confirmed capability to produce cellulolytic and xylanolytic enzymes. The strain originated from the local culture collection of the Department of Biotechnology and Food Microbiology 
of the Wroclaw University of Environmental and Life Sciences (Wroclaw, Poland), stored in a PDA (potato dextrose agar; Merck Millipore, Burlington, MA, USA) medium at $4{ }^{\circ} \mathrm{C}$.

The process of ethanol fermentation was performed using dried culture of industrial distillery yeast Saccharomyces cerevisiae SIHA Active Yeast 6 strain DF 639 (EATON, Irvine, CA, USA) stored as recommended.

\subsection{Waste Biomass of Sweet Sorghum}

The experimental material included sweet sorghum (Sorghum bicolor (L.) Moench) of hybrid type Sucrosorgo 506, grown at the Research and Experimental Station of the Wrocław University of Environmental and Life Sciences (Pawłowice, Poland), characterized by $23.95 \%$ of dry matter, of which $41.49 \%$ was cellulose and $21.61 \%$ hemicellulose.

\subsection{Production of the Enzymatic Preparation}

As an inducer of cellulo- and xylanolytic enzymes, two waste raw materials were used: Sugar beet pulp (Sugar mill, Wałbrzych, Poland) and wheat bran (Department of Fermentation and Cereals Technology, Wrocław University of Environmental and Life Sciences). A sterile culture medium composed of sugar beet pulp and wheat bran (1:1) was inoculated with a suspension of T. citrinoviride $\mathrm{C} 1$ strain spores to the initial density of $5 \times 10^{6}$ spores $\mathrm{g}^{-1}$ medium. The solid state culture of $70 \%$ initial moisture was run at a temperature of $25{ }^{\circ} \mathrm{C}$ for 10 days under $24 \mathrm{~h}$ lighting in a KBWF 720 growth chamber (Binder $\mathrm{GmbH}$, Tuttlingen, Germany). It was terminated by extraction using $0.05 \mathrm{M}$ acetate buffer with $\mathrm{pH} 4.8$ and agitated at room temperature for $30 \mathrm{~min}$ (160 rpm).

The enzymatic preparation (C1) was obtained by a four-fold concentration of the post-culture extract via ultrafiltration at a temperature of $4{ }^{\circ} \mathrm{C}$. Ultrafiltration was performed using the Labscale TFF System (Merck Millipore, Burlington, MA, USA) with a Pellicon XL Ultrafiltration Module Biomax (polyethylsulfone membrane) with the cut-off point of $10 \mathrm{kDa}$.

\subsection{Acidic Pre-Hydrolysis of Sweet Sorghum Biomass}

Disintegrated waste biomass of sweet sorghum was subjected to high-temperature acidic pre-hydrolysis ( $2 \%$ sulfuric acid (VI), $150{ }^{\circ} \mathrm{C}, 1 \mathrm{~h}$, WTB Binder dryer, Binder $\mathrm{GmbH}$, Tuttlingen, Germany). The waste material was used in various concentrations (15, 21, and 27\% w/w) according to the adopted optimization model (see section Results, Table 2). The pre-hydrolysates were cooled, their $\mathrm{pH}$ was adjusted to values of $4.5,5.0$, and 5.5 , using $1 \mathrm{M}$ solution of sodium hydroxide, and used in the process of enzymatic hydrolysis.

\subsection{Optimization of the Enzymatic Hydrolysis of Sweet Sorghum Waste Biomass}

Enzymatic hydrolysis was conducted in Erlenmayer flasks $(100 \mathrm{~mL})$ incubated in a GFL 1083 water bath (Bionovo, Legnica, Poland) at temperatures of $42^{\circ} \mathrm{C}, 50^{\circ} \mathrm{C}$, and $58^{\circ} \mathrm{C}$ at $120 \mathrm{rpm}$ for $48 \mathrm{~h}$ (see section Results, Table 2) using the concentrated preparation $\mathrm{C} 1$ in a dose corresponding to $2.15 \mathrm{U}$ of endocellulases (CMCases) per $10 \mathrm{~g}$ of substrate. To determine the effectiveness of the enzymatic preparation obtained under laboratory conditions, a commercial enzymatic preparation Cellic ${ }^{\circledR} \mathrm{CTec} 2$ (further referred to as CTec2) (Novozymes, Kobenhavn, Denmark) was used for hydrolysis under analogous conditions.

The response surface methodology (RSM) was used to optimize conditions of enzymatic hydrolysis and to evaluate its usability for the process of ethanol fermentation. The RSM enables determining the main effects and interactions between selected independent variables (substrate concentration $\mathrm{X}_{1}$, temperature $\mathrm{X}_{2}$, and $\mathrm{pH} \mathrm{X}_{3}$ ) on the yield of ethanol fermentation process (dependent variable). Three levels $(-1,0,+1)$ were adopted in the Box-Behnken design for each of the independent variables $\left(\mathrm{X}_{1}: 15 \%, 21 \%, 27 \% ; \mathrm{X}_{2}: 42{ }^{\circ} \mathrm{C}, 47^{\circ} \mathrm{C}, 58^{\circ} \mathrm{C}\right.$; and $\left.\mathrm{X}_{3}: 4.5,5.0,5.5\right)$. The detailed experimental layout is presented in Table 2. 
The following polynomial equation was fitted to describe a correlation between independent variables, including linear $\left(\beta_{1}, \beta_{2}, \beta_{3}\right)$, quadratic $\left(\beta_{11}, \beta_{22}, \beta_{33}\right)$, and interaction terms $\left(\beta_{12}, \beta_{13}, \beta_{23}\right)$ and the response $(\mathrm{Y})$.

$$
Y=\beta_{0}+\beta_{1} X_{1}+\beta_{2} X_{2}+\beta_{3} X_{3}+\beta_{11} X_{1} X_{1}+\beta_{22} X_{2} X_{2}+\beta_{33} X_{3} X_{3}+\beta_{12} X_{1} X_{2}+\beta_{13} X_{1} X_{3}+\beta_{23} X_{2} X_{3}
$$

Results obtained were subjected to the regression analysis and to the analysis of variance (ANOVA), using Statistica software ver. 12.5 (StatSoft, Kraków, Poland). The effects were summarized and insignificant terms, with confidence interval $(p)$ higher than 0.5 , were removed from the model.

\subsection{Ethanol Fermentation Process}

The hydrolysates were subjected to periodic ethanol fermentation in Erlenmayer flasks (100 mL) with industrial distillery yeast Saccharomyces cerevisiae SIHA Active Yeast 6 (EATON, Irvine, CA, USA) used in the concentration of $0.2 \mathrm{~g} \mathrm{~L}^{-1}$, rehydrated in sterile distilled water right before the process. The fermentation process was performed in Binder incubator (BINDER, Tuttlingen, Germany) at a temperature of $37^{\circ} \mathrm{C}$ for $72 \mathrm{~h}$.

\subsection{Analytical Analyses}

\subsubsection{Enzyme Activity Assay and Protein Concentration Determination}

The enzymatic activities of cellulases (CMCases, EC 3.2.1.4) and endoxylanases (EC 3.2.1.8) in extracts from solid state cultures, as well as in the concentrated preparation $\mathrm{C} 1$ and commercial Cellic CTec2, were determined according to the methods described in the literature [43], using DNS reagent [44]. The unit of enzyme activity was expressed as the amount of enzyme which liberates 1 $\mu \mathrm{mol}$ of glucose or xylose per minute per $1 \mathrm{~mL}\left(\mathrm{U} \mathrm{mL}^{-1}\right)$. To determine specific activity $\left(\mathrm{U} \mathrm{mg}^{-1}\right)$, protein concentration was determined with Lowry's method [45].

\subsubsection{HPLC Analysis}

Concentrations of glucose (glu), arabinose (arab), and a mixture of galactose + xylose + mannose (gal, xyl, man) were determined with high-performance liquid chromatography (HPLC) in the Dionex Ultimate 3000 system (Thermo Scientific, Waltham, MA, USA), using an Aminex HPX-87H column (Bio-Rad, EATON, Irvine, CA, USA) coupled with a UV $(\lambda=210 \mathrm{~nm})$ and IR detectors. Analyses were carried out at a temperature of $35^{\circ} \mathrm{C}$, with $0.01 \mathrm{M}$ sulfuric acid (VI) used as the mobile phase at the flow rate of $0.6 \mathrm{~mL} \mathrm{~min}{ }^{-1}$.

Hydrolysis yield expressed in \% was calculated as follows:

Yield $[\%]=($ concentration of reducing sugars released $\times 0.9 \times 100) /$ weight of sweet sorghum residues.

Ethanol concentration in the post-fermentation liquids was determined with the liquid chromatography using a Shimadzu Prominence system with RID detector-10A (Shimadzu, Kyoto, Japan). Samples centrifuged at 15,000 rpm for $10 \mathrm{~min}$ were filtered using a syringe filter (pore diameter $0.22 \mu \mathrm{m})$. Separation conditions were as follows: Security Guard Cartridges Carbo-Pb pre-column $(4 \times 3.0 \mathrm{~mm}$ ID) (Phenomenex, Torrance, MA, USA), Rezex ROA-Organic Acid H+ column $(300 \times 7.8 \mathrm{~mm})$ (Phenomenex, Torrance, MA, USA), eluent $-0.005 \mathrm{M} \mathrm{H}_{2} \mathrm{SO}_{4}$, mobile phase flow rate $-0.6 \mathrm{~mL} \mathrm{~min}^{-1}$, temperature $60^{\circ} \mathrm{C}$, and injection volume $-20 \mu \mathrm{L}$. Chromatograms were analyzed in Chromax 10 software (Pol-Lab, Poland).

Process yield was expressed in $\mathrm{mL}$ of $100 \%$ ethanol per kg of substrate dry matter $\left(\mathrm{mL} \mathrm{kg} \mathrm{d.m.}^{-1}\right)$ and in $\mathrm{mL}$ of $100 \%$ ethanol per $\mathrm{kg}$ of total sugars content $\left(\mathrm{mL} \mathrm{kg} \mathrm{sugars}^{-1}\right)$. According to the stoichiometric equations of the ethanol fermentation process of pentoses and hexoses, the theoretical ethanol yield was calculated from the total amount of sugars in the hydrolysates (\% of theoretical yield). 


\section{Conclusions}

The assumption of this study was to determine the usefulness of the enzyme preparation T. citrinoviride $\mathrm{C} 1$ obtained in laboratory conditions in the bioethanol production process and its effectiveness was compared with the commercial CTec2 preparation used for this purpose. The enzyme preparation $\mathrm{C} 1$ was obtained with the use of lignocellulose waste materials, which solves the problem of managing these types of waste and additionally indicates the possibility of using them as a carbon and energy sources in the production of biotechnological enzymes. Comparing the effects of the $\mathrm{C} 1$ enzyme cocktail and the commercial preparation $\mathrm{CTec} 2$, differences in ethanol production efficiency were observed with a slight advantage in favor of the CTec2. However, it should be mentioned that when using it you have to take into account higher costs. Optimal process conditions with $\mathrm{C} 1$ enzyme cocktail were determined and they were as follows: Substrate concentration $22.6 \%$, temperature $50.5^{\circ} \mathrm{C}$, and $\mathrm{pH} 5.1$; they allowed achieving ethanol yield at $122.5 \mathrm{~mL} \mathrm{~kg} \mathrm{d.m.}{ }^{-1}$. The presented results indicate the possibility of further process improvement with the application of $\mathrm{C} 1$ preparation, including the use of other waste materials, different fermentation systems or the scale-up of the process, which may additionally affect its efficiency.

Supplementary Materials: The following are available online at http://www.mdpi.com/2073-4344/10/11/1292/s1, Figure S1: Comparison of ethanol yield after a fermentation of hydrolysates obtained under various conditions with (a) C1 and (b) CTec2 enzymes, Figure S2: Prediction profiles for experimental models of SHF processes with using (a) C1 and (b) CTec2 enzymes (blue lines- confidence interval, green lines- standard error, red lines-designated optimum), Table S1: Analysis of variance (ANOVA) for the obtained regression model for the ethanol yield in SHF processes with $\mathrm{C} 1$ and $\mathrm{CTec} 2$ enzymes

Author Contributions: Conceptualization, A.K. and J.C.; Methodology, A.K., J.C., P.K.; Software, W.Ł., P.K.; Writing-Original Draft Preparation, A.K., J.C.; Writing-Review \& Editing, A.K., W.E. All authors have read and agreed to the published version of the manuscript.

Funding: The research was supported by the Wroclaw Centre of Biotechnology under the Leading National Research Centre (KNOW) programme for years 2014-2018. The manuscript is financed under the Leading Research Groups support project from the subsidy increased for the period 2020-2025 in the amount of 2\% of the subsidy referred to Art. 387 (3) of the Law of 20 July 2018 on Higher Education and Science, obtained in 2019.

Conflicts of Interest: The authors declare no conflict of interest.

\section{References}

1. Aditiya, H.B.; Mahlia, T.M.I.; Chong, W.T.N.; Hadi Sebayang, A.H. Second generation bioethanol production: A critical review. Renew. Sustain. Energy Rev. 2016, 66, 631-653. [CrossRef]

2. Thanapimmetha, A.; Saisriyoot, M.; Khomlaem, C.; Chisti, Y.; Srinophakun, P. A comparison of methods of ethanol production from sweet sorghum bagasse. Biochem. Eng. J. 2019, 151, 107352. [CrossRef]

3. Gnansounou, E.; Dauriat, A.; Wyman, C. Refining sweet sorghum to ethanol and sugar: Economic trade-offs in the context of North China. Bioresour. Technol. 2005, 96, 985-1002. [CrossRef] [PubMed]

4. Liang, Y.; Yesuf, J. Optimization of sugar release from sweet sorghum bagasse following solvation of cellulose and enzymatic hydrolysis using response surface methodology. Biotechnol. Prog. 2013, 30, 367-375.

5. Matyka, M.; Księżak, J.; Witorożec, A. Wpływ poziomu nawożenia azotem na plonowanie sorga dwubarwnego (Sorghum bicolor (L.) Moench) uprawianego w zróżnicowanych warunkach siedliskowych. Pol. J. Agron. 2017, 29, 28-34. (In Polish)

6. Mathur, S.; Umakanth, A.V.; Tonapi, V.A.; Sharma, R.; Sharma, M.K. Sweet sorghum as biofuel feedstock: Recent advances and available resources. Biotechnol. Biofuels 2017, 10, 146. [CrossRef] [PubMed]

7. Galbe, M.; Zacchi, G. Pretreatment of lignocellulosic materials for efficient bioethanol production. Biofuels Adv. Biochem. Eng. Biotechnol. 2007, 108, 41-65.

8. Kucharska, K.; Rybarczyk, P.; Hołowacz, I.; Łukajtis, R.; Glinka, M.; Kamiński, M. Pretreatment of lignocellulosic materials as substrates for fermentation processes. Molecules 2018, 23, 2937. [CrossRef]

9. Jayasekara, S.; Ratnayake, R. Microbial Cellulases: An Overview and Applications; IntechOpen Limited: London, UK, 2019.

10. Treichel, H.; Oliveira, D.; Mazutti, M.; Di Luccio, M.; Oliveira, J.V. A Review on microbial lipases production. Food Bioprocess Technol. 2010, 3, 182-196. [CrossRef] 
11. Knob, A.; Fortkamp, D.; Prolo, T.; Izidoro, S.C.; Almeida, J.M. Agro-residues as alternative for xylanase production by filamentous fungi. BioResources 2014, 9, 5738-5773.

12. Farinas, C.S. Developments in solid-state fermentation for the production of biomass-degrading enzymes for the bioenergy sector. Renew. Sustain. Energy Rev. 2015, 52, 179-188. [CrossRef]

13. Mejias, L.; Cerda, A.; Barrena, R.; Gea, T.; Sanchez, A. Microbial strategies for cellulase and xylanase production through solid-state fermentation of digestate from biowaste. Sustainability 2018, 10, 2433. [CrossRef]

14. Amin, F.; Bhatti, H.N.; Bilal, M. Recent advances in the production strategies of microbial pectinases-A review. Int. J. Biol. Macromol. 2019, 122, 1017-1026. [CrossRef] [PubMed]

15. Manan, M.A.; Webb, C. Modern microbial solid state fermentation technology for future biorefineries for the production of added-value products. Biofuel Res. J. 2017, 4, 730-740. [CrossRef]

16. Sadh, P.; Duhan, S.; Duhan, J. Agro-industrial wastes and their utilization using solid state fermentation: A review. Bioresour. Bioprocess. 2018, 5, 1-15. [CrossRef]

17. Appiah-Nkansah, N.B.; Li, J.; Rooney, W.; Wang, D. A review of sweet sorghum as a viable renewable bioenergy crop and its techno-economic analysis. Renew. Energy 2019, 143, 1121-1132. [CrossRef]

18. Piegza, M.; Łaba, W.; Kancelista, A.; Witkowska, D.; Kawa-Rygielska, J. Evaluation of brewer's spent grain as a substrate for Trichoderma hydrolytic enzymes production and source of majorly fermentable sugars. Acta Sci. Pol. Biotechnol. 2015, 14, 7-32.

19. Mala, J.G.; Edwinoliver, N.G.; Kamini, N.R.; Puvanakrishnan, R. Mixed substrate solid state fermentation for production and extraction of lipase from Aspergillus niger MTCC 2594. J. Gen. Appl. Microbiol. 2007, 53, 247-253. [CrossRef]

20. Idris, A.; Pandey, A.; Rao, S.; Sukumaran, R.K. Cellulase production through solid-state tray fermentation, and its use for bioethanol from sorghum stover. Bioresour. Technol. 2017, 242, 265-271. [CrossRef] [PubMed]

21. Juturu, V.; Wu, J. Microbial cellulases: Engineering, production and applications. Renew. Sustain. Energy Rev. 2014, 33, 188-203. [CrossRef]

22. Amore, A.; Pepe, O.; Ventorino, V.; Birolo, L.; Giangrande, C.; Faraco, V. Industrial waste based compost as a source of novel cellulolytic strains and enzymes. FEMS Microbiol. Lett. 2013, 339, 93-101. [CrossRef] [PubMed]

23. Kachlishvili, E.; Penninckx, M.J.; Tsiklauri, N.; Elisashvili, V. Effect of nitrogen source on lignocellulolytic enzyme production by white-rot basidiomycetes under solid-state cultivation. World J. Microbiol. Biotechnol. 2006, 22, 391-397. [CrossRef]

24. Elisashvili, V.; Kachlishvili, E.; Asatiani, M. Shiitake medicinal mushroom, Lentinus edodes (Higher Basidiomycetes) productivity and lignocellulolytic enzyme profiles during wheat straw and tree leaf bioconversion. Int. J. Med. Mushrooms 2015, 17, 77-86. [CrossRef]

25. Sarris, D.; Papanikolaou, S. Biotechnological production of ethanol: Biochemistry, processes and technologies. Eng. Life Sci. 2016, 16, 307-329. [CrossRef]

26. Ellilä, S.; Fonseca, L.; Uchima, C.; Cota, J.; Goldman, G.H.; Saloheimo, M.; Sacon, V.; Siika-aho, M. Development of a low cost cellulose production process using Trichoderma reesei for Brazilian biorefineries. Biotechnol. Biofuels 2017, 10, 30. [CrossRef]

27. Cunha, F.M.; Badinoa, A.C.; Farinas, C.S. Effect of a novel method for in-house cellulase production on 2G ethanol yields. Biocatal. Agric. Biotechnol. 2017, 9, 224-229. [CrossRef]

28. Kovacs, K.; Macrelli, S.; Szakacs, G.; Zacchi, G. Enzymatic hydrolysis of steam-pretreated lignocellulosic materials with Trichoderma atroviride enzymes produced in-house. Biotechnol. Biofuels 2009, 2, 14. [CrossRef]

29. Qi, B.; Luo, J.; Chen, G.; Chen, X.; Wan, Y. Application of ultrafiltration and nanofiltration for recycling cellulase and concentrating glucose from enzymatic hydrolyzate of steam exploded wheat straw. Bioresour. Technol. 2011, 104, 466-472. [CrossRef] [PubMed]

30. Mores, W.; Knutsen, J.; Davis, R. Cellulase recovery via membrane filtration. Appl. Biochem. Biotechnol. 2001, 91, 297-309. [CrossRef]

31. Głąb, L.; Sowiński, J.; Chmielewska, J.; Prask, H.; Furgol, M.; Szlachta, J. Comparison of the energy efficiency of methane and ethanol production from sweet sorghum (Sorghum bicolor (L.) Moench) with a variety of feedstock management technologies. Biomass Bioenergy 2019, 129, 105332. [CrossRef] 
32. Cao, W.; Sun, C.; Liu, R.; Yin, R.; Wu, X. Comparison of the effects of five pretreatment methods on enhancing the enzymatic digestibility and ethanol production from sweet sorghum bagasse. Bioresour. Technol. 2012, 111, 215-221. [CrossRef]

33. Teixeira, V.S.; Azambuja, S.P.H.; Carvalho, P.H.; Costa, F.A.A.; Kitaka, P.R.; Stekelgerb, C.; Andrietta, S.R.; Andrietta, M.G.S.; Goldbeck, R. Robustness and ethanol production of industrial strains of Saccharomyces cerevisiae using different sugarcane bagasse hydrolysates. J. Appl. Biotechnol. 2019, 7, 23-38. [CrossRef]

34. Ramarajan, R.; Manohar, C.S. Biological pretreatment and bioconversion of agricultural wastes, using ligninolytic and cellulolytic fungal consortia. Bioremediation J. 2017, 21, 89-99. [CrossRef]

35. Isroi, I.; Millati, R.; Syamsiah, S.; Niklasson, C.; Cahyanto, M.N.; Lundquist, K.; Taherzadeh, M.J. Biological treatment of Lignocelluloses with white-rot fungi and its applications: Review. Bioresources 2011, 6, 5224-5259.

36. Gibbons, W.; Westby, C.; Dobbs, T. Intermediate-scale, semicontinuous solid-phase fermentation process for production of fuel ethanol from sweet sorghum. Appl. Environ. Microbiol. 1986, 51, 115-122. [CrossRef]

37. Kim, M.; Day, D. Composition of sugar cane, energy cane, and sweet sorghum suitable for ethanol production at Louisisna sugar mills. J. Ind. Microbiol. Biotechnol. 2011, 38, 803-807. [CrossRef]

38. Salvi, D.; Aita, G.; Robert, D.; Bazan, V. Ethanol production from sorghum by dilute ammonia pretreatment. J. Ind. Microbiol. Biotechnol. 2009, 36, 27-34. [CrossRef] [PubMed]

39. Shen, F.; Saddler, J.; Liu, R.; Lin, L.; Deng, S.; Zhang, Y.; Yang, G.; Xiao, H.; Li, Y. Evaluation of steam pretreatment on sweet sorghum bagasse for enzymatic hydrolysis and bioethanol production. Carbohydr. Polym. 2011, 86, 1542-1548. [CrossRef]

40. Cotana, F.; Cavalaglio, G.; Gelosia, M.; Coccia, V.; Petrozzi, A.; Ingles, D.; Pompili, E. A comparison between SHF and SSSF processes from cardoon for ethanol production. Ind. Crops Prod. 2015, 69, 424-432. [CrossRef]

41. Liu, R.; Li, J.; Shen, J. Refining bioethanol from stalk juice of sweet sorghum by immobilized yeast fermentation. Renew. Energy 2008, 33, 1130-1135. [CrossRef]

42. Laopaiboon, L.; Nuanpeng, S.; Srinophakun, P.; Klanrit, P.; Laopaiboon, P. Ethanol production from sweet sorghum juice using very high gravity technology: Effects of carbon and nitrogen supplementations. Bioresour. Technol. 2009, 100, 4176-4182. [CrossRef] [PubMed]

43. Witkowska, D.; Wróblewska, A.; Jurgielewicz, W. Degradation of cellulose and lignocellulose by Trichoderma reesei M7-1 hydrolases. Pol. J. Food Nutr. Sci. 1997, 6, 57-62.

44. Miller, G.L. Use dinitrosalicylic acid reagent for determination of reducing sugars. Anal. Chem. 1959, 31, 426-428. [CrossRef]

45. Lowry, O.H.; Rosebrough, N.J.; Farr, A.L.; Randall, R.J. Protein measurement with the Folin phenol reagent. J. Biol. Chem. 1951, 193, 265-275.

Publisher's Note: MDPI stays neutral with regard to jurisdictional claims in published maps and institutional affiliations.

(C) 2020 by the authors. Licensee MDPI, Basel, Switzerland. This article is an open access article distributed under the terms and conditions of the Creative Commons Attribution (CC BY) license (http://creativecommons.org/licenses/by/4.0/). 